\title{
Comparative attractancy of physical and chemical stimuli to aedine mosquitoes *
}

\author{
Yoshiyasu KuSAKaBE** and Toshiaki Ikeshoj ${ }^{* *}$ \\ Department of Agrobiology, Faculty of Agriculture, The University of Tokyo, \\ Bunkyo-ku, Tokyo 113, Japan
}

(Received: October 3, 1989)

\begin{abstract}
Key words: comparative attractancy, Aedes, heat, sound, lactic acid, trap.
\end{abstract}
\begin{abstract}
Trapping of both sexes of mosquitoes achieves more efficient control than manipulating the male population. For this purpose, various chemical and physical stimuli known to be attractive were reevaluated. Heat, black color, Llactic acid, movement and sound were all attractive to both sexes of Aedes aegypti when tested individually under laboratory conditions. Black color, heat and lactic acid in this order contributed their attractancy in combinations with the other stimuli. In field tests at the fringe of a forest, however, only heat and sound proved to be of significant attractancy for female and male of Aedes albopictus, respectively. From these tests, it was suggested a powerful attractant from human emanations and optokinetic stimulus was necessary for further improvement of mosquito traps.
\end{abstract}

\section{INTRODUCTION}

Male mosquitoes are attracted to and effectively manipulated by acoustic sound (Ikeshoji et al., 1985 for Culex tarsalis; Ikeshoji, 1986 for Culex tritaeniorhynchus; Ikeshoji and Yap, 1987 for Culex quinquefasciatus; Ikeshoji and Ogawa, 1988 for Aedes albopictus; Kanda et al., 1987 for Mansonia spp.; Leemingsawat, 1989 for Anopheles minimus and Anopheles maculatus). However, mass trapping and autochemosterilization of both sexes rather than the male alone are more efficient for their control (Ikeshoji et al., 1990).

* This work was supported in part by a Grantin-Aid for Overseas Scientific Survey No. 01044130 from the Ministry of Education, Science and Culture of Japan.

** 日下部良康, 池庄司敏明: 東京大学農学部害虫学 教室（干113 東京都文京区弥生 1-1-1)
Kanda et al. (1987) and Leemingsawat (1989) used a hamster and dry ice in addition to sound to attract females and more males. Animal traps are, however, not feasible for a control program because of their cost and handling difficulties. A good female trap may also replace the human bait trap employed in mosquito surveys.

For the practical purpose in mind, therefore, the attractancy of various known stimuli was reevaluated in the present paper. These include heat, humidity, lactic acid, carbon dioxide, visual factors such as black color and target movement, and sound (Clements, 1963). Except for sound, these stimuli have hitherto rarely been studied against males.

\section{Methods}

Laboratory experiment. Thirty 3- or 4day-old, laboratory-bred virgin males or mated females of Aedes aegypti were placed in a $30 \times 30-\mathrm{cm}$ wide and $60-\mathrm{cm}$ deep acryl 
box, the bottom and end of which were screened and well ventilated by raising the box $30 \mathrm{~cm}$ above the floor. Seven stimuli: heat, humidity, lactic acid, color, carbon dioxide, movement and sound were tested individually and in different combinations against control. The first five stimuli were delivered through a 2-cm diam. glass tube which was passed between two holes on the side walls at $10 \mathrm{~cm}$ from the front and $20 \mathrm{~cm}$ from the bottom. The tube was sectioned in two; one half was treated with stimuli and the other kept as control, or vice versa. The tube was wrapped with the following materials of different shades to test color preference; a white filter paper (W), gray or black painted papers (G1-3, B1 and B4), a black blotting paper (B2), a black polyethylene sheet (B3) and a carbon blackcoated paper (B5). Heat was delivered through the tube by circulating water heated to $30-50^{\circ} \mathrm{C}$. For the heat vs, unheated experiments, two half length tubes were used. Humidity and L-lactic acid were treated onto the paper or sheet by pipetting $1.5 \mathrm{ml}$ of water and the acetone solution of different concentrations, respectively. A regulated volume of $\mathrm{CO}_{2}$ was released at a few $\mathrm{cm}$ height over the tube with a glass capillary connected to a gas bomb. To test optokinetic sense, a 4-cm square B2 paper with or without a 3-cm diam. dynamic speaker was tied on the $20-\mathrm{cm}$ arm of a metronome and swayed horizontally at a speed of $8.7 \mathrm{~cm} / \mathrm{sec}$. A 400 $\mathrm{Hz}$ sinusoidal sound was generated at 5 -sec intervals by a handmade generator (Ikeshoji et al., 1990). The experiment was done under a 240 to $300 \mathrm{~lx} \mathrm{dim} \mathrm{light} \mathrm{at} 27^{\circ} \mathrm{C}$ and 80-90\% RH around 16:00 when flight activity was highest. Accumulated frequencies of alighting on the tube were counted by the naked eyes or a video camera at $1-\mathrm{m}$ distance from the front acryl wall for $5 \mathrm{~min}$ $\times 3$ times for each observation and each experiment was replicated 3 to 7 times.

The light absorption spectra of the colored papers and the polyethylene sheet were measured with a Shimadzu TLG scanner, CS 920.

Field experiment. Different combinations of the attractive stimuli: heat, sound and dry ice were tested with black color. The trap consisted of an $80 \times 90-\mathrm{cm}$ black poly- ethylene bag (B3), to the inside of which was taped a $90-\mathrm{cm}$ dynamic speaker, a thin Samiconplate heater $(20 \times 30-\mathrm{cm}$ wide, $230 \mathrm{~V}$ $48 \mathrm{~W}$, Sakaguchi Dennetsu Co., Tokyo), and a $40^{\circ} \mathrm{C}$ temperature regulator ( $\mathrm{F} 1$ type). The bag was hung at 1-m height from a bar crossing two tripods and set in half shade at the fringe of a bush back of the Universiti Sains Malaysia campus in Penang. The place was surrounded by few houses, a sheep pen and the brook at 20-30-m distances, and seemingly infested with inexhaustible number of $A e$. albopictus. Out surface of the bag was sprayed with adhesive (Kinryu, Showa Denko Co., Tokyo). The $400-\mathrm{Hz}$ sound was generated as above. One $\mathrm{kg}$ of dry ice was placed on the ground under the trap. Each test lasted only for $10 \mathrm{~min}$, and a few tests was made daily at random times from 7:00 to 20:00. Trapped Ae. albopictus were counted (smaller numbers of Mansonia uniformis and $C x$. quinquefasciatus trapped were not counted) and removed with a forceps each time.

\section{Results}

\section{Laboratory experiment}

Optimum intensities of various stimuli. Heat was significantly attractive to $A e$. aegypti female at 36 and $40^{\circ} \mathrm{C}$ against the ambient temperature of $27^{\circ} \mathrm{C}$ (Table 1 ). The high attractancy to male at $40^{\circ} \mathrm{C}$ was partly due to the unattractive white paper (W) used for the control as later shown in the color test of black paper B2 vs. W. Humidity was not attractive to male as dry control. Lactic acid was attractive at the dosage of 0.012 and $0.12 \mathrm{mg} / \mathrm{cm}^{2}$ to female and male, respectively, but repellent at 1.2 $\mathrm{mg} / \mathrm{cm}^{2}$ to female. $\mathrm{CO}_{2}$ was not attractive to both sexes at all dosages tested. When W, G1-3 and B1-4 papers or polyethylene sheet were tested to female against the most attractive B5 paper (refer Fig. 1 for the light absorption spectra), W attracted minimum, whereas all the others were equally less attractive to female than B5 control. However, B2 was highly attractive to male when tested against W. A 4-cm square B2 paper in a horizontal movement at $8.7 \mathrm{~cm} / \mathrm{sec}$ speed was also slightly attractive to male, and so was this with sound to both female and male. 
Table 1 Percentages of Aedes aegypti responded to various stimuli at different intensities against total numbers responded.

\begin{tabular}{|c|c|c|c|}
\hline Stimuli & Intensity & Female & Male \\
\hline \multirow[t]{5}{*}{ Heat } & $30^{\circ} \mathrm{C}$ & $52^{* 1, a, b}$ & - \\
\hline & 36 & $59 \mathrm{~s}, \mathrm{a}, \mathrm{c}$ & - \\
\hline & 40 & $62^{s, b, d, e, f}$ & $74^{* 2, \mathrm{~s}}$ \\
\hline & 45 & $53^{\ominus}$ & - \\
\hline & 50 & $51^{\mathrm{c}, \mathrm{d}, \mathrm{f}}$ & - \\
\hline \multirow{2}{*}{\multicolumn{2}{|c|}{$\begin{array}{l}\text { Humidity } 1.5 \mathrm{ml} \mathrm{H} \mathrm{H}_{2} \mathrm{O} \\
\text { Lactic acid }\end{array}$}} & - & $62^{* 3}$ \\
\hline & & & \\
\hline \multicolumn{2}{|c|}{$0.012 \mathrm{mg} / \mathrm{cm}^{2}$} & $59^{* 4, \mathrm{~s}, \mathrm{a}}$ & $56^{* 5}$ \\
\hline & 0.12 & $75^{\mathrm{s}, \mathrm{a}, \mathrm{b}}$ & $65^{s, a}$ \\
\hline & 1.2 & $40^{\mathrm{s}, \mathrm{b}}$ & $43^{a}$ \\
\hline \multirow[t]{3}{*}{$\mathrm{CO}_{2}$} & $10 \mathrm{ml} / \mathrm{min}$ & $52^{* 4}$ & - \\
\hline & 50 & 57 & $60^{* 5}$ \\
\hline & 100 & 62 & 55 \\
\hline \multirow[t]{8}{*}{ Color*6 } & W & $3^{* 7, \mathrm{~s}, \mathrm{a}-\mathrm{f}}$ & - \\
\hline & G1 & $35^{\mathrm{s}, \mathrm{a}}$ & - \\
\hline & $\mathrm{G} 2$ & $35^{\mathrm{s}, \mathrm{b}}$ & - \\
\hline & G3 & $38^{\mathrm{s}, \mathrm{c}}$ & - \\
\hline & B1 & $40^{\mathrm{s}, \mathrm{d}}$ & - \\
\hline & $\mathrm{B} 2$ & - & $80^{* 8, \mathrm{~s}}$ \\
\hline & B3 & $42^{\mathrm{s}, \mathrm{\theta}}$ & - \\
\hline & B4 & $33^{\mathrm{s}, \mathrm{f}}$ & - \\
\hline Move & $8.7 \mathrm{~cm} / \mathrm{sec}$ & - & $66^{* 9, \mathrm{~s}}$ \\
\hline \multicolumn{2}{|c|}{ Move + sound } & $67^{* 10, \mathrm{~s}}$ & $62^{\mathrm{s}}$ \\
\hline
\end{tabular}

${ }^{* 1}$ Tested with black paper $\mathrm{B} 2$ against $27^{\circ} \mathrm{C}$ control. ${ }^{* 2}$ Tested with $\mathrm{B} 2$ against white paper $\mathrm{W}$ at $27^{\circ} \mathrm{C}$. ${ }^{* 3}$ Tested with $\mathrm{W} .{ }^{* 4}$ Tested with $\mathrm{W}$ at $40^{\circ} \mathrm{C}$. ${ }^{* 5}$ Tested with $\mathrm{W}$ at $27^{\circ} \mathrm{C}$. ${ }^{* 6}$ Color spectra are shown in Fig. $1 .{ }^{* 7}$ Tested at $40^{\circ} \mathrm{C}$ against B5. ${ }^{* 8}$ Tested at $40^{\circ} \mathrm{C}$ against $\mathrm{W}$. ${ }^{* 8}$ Tested with $\mathrm{B} 2$ against nonmoving control. ${ }^{* 10}$ Tested with $\mathrm{B} 2$ and sound against non-moving control. s Percentages are significantly different from $50 \%$ by Binomial Tests (one side test). a-f Percentages with the same letters in each test group are significantly different by Randomization Tests for Two Independent Samples.

Comparative attractancy of various stimuli. Five stimuli were tested in different combinations at their optimum concentrations; heat at $36^{\circ} \mathrm{C}$, humidity of $1.5 \mathrm{ml}$ water, $0.12 \mathrm{mg} /$ $\mathrm{cm}^{2}$ of lactic acid, B2 paper (this was used instead of $\mathrm{B} 5$ ) and $50 \mathrm{ml} / \mathrm{min}$ of $\mathrm{CO}_{2}$. When one stimulus was omitted from a combination of all five stimuli which was used as the

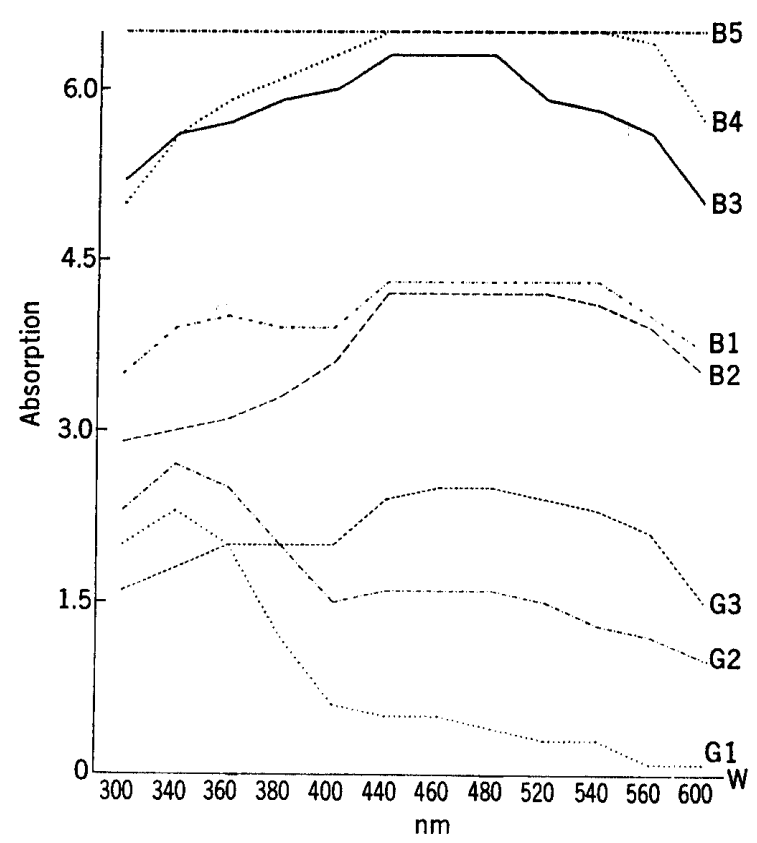

Fig. 1 Light absorption spectra of various visual targets.

control, the heat, black color or lactic acidomitted combinations (combination 1, 3 and 4) reduced the attractancy significantly to female (in Fig. 2, $\mathrm{S}$ shows the mean percentage significantly different from $50 \%$ by binomial test, one side test). The humidityomitted combination (2) reduced no attractancy, and significantly differed from the three combinations when tested by randomization test for two independent samples, one side test. The $\mathrm{CO}_{2}$-omitted combination (5, 6 ), however, did not differ from the control. Among the four combinations excluding three stimuli $(7-10)$, the heat, humidity and black color-omitted combination (10) reduced attractancy most. When the three four stimuli-omitted combinations or single stimuli (11-13) were tested, the heat (11) and the lactic acid (12) reduced attractancy significantly more than the black color (13). In other words, black color was most attractive, followed by heat and lactic acid.

Against male, attractancy was quite variable. Only the heat-omitted combination (14) reduced attractancy among the three one stimulus-omitted combinations (14-16). In contrast, two combinations omitting $\mathrm{CO}_{2}$ $(16,17)$ somewhat increased attractancy. In other words, $\mathrm{CO}_{2}$ was repellent under the present condition. In spite of the repellency 

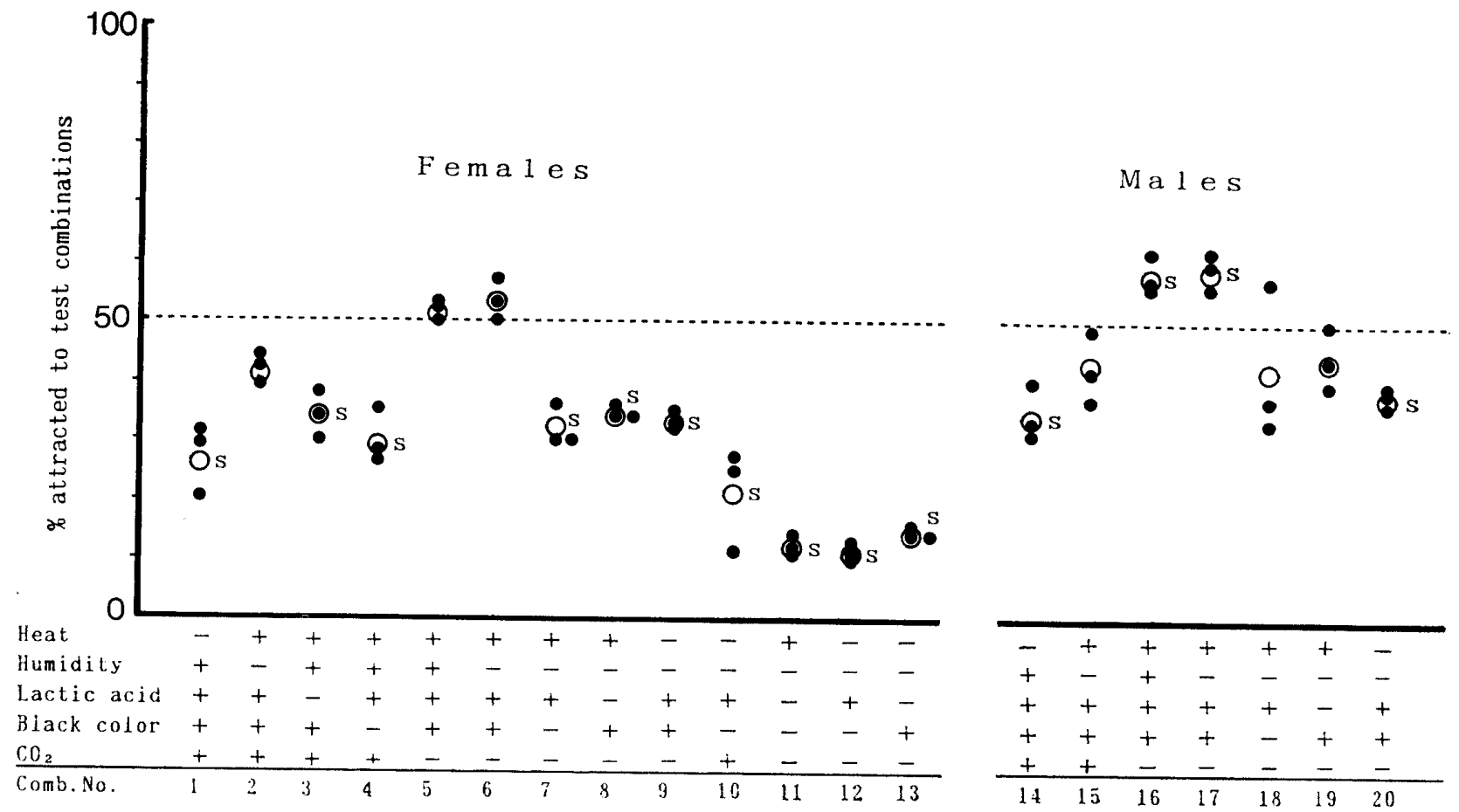

Fig. 2 Relative attractancy of five stimuli in various combinations to Aedes aegypti. The open circle shows the mean percentage and $\mathrm{S}$ shows its significance from $50 \%$ by binomial test, one side test.

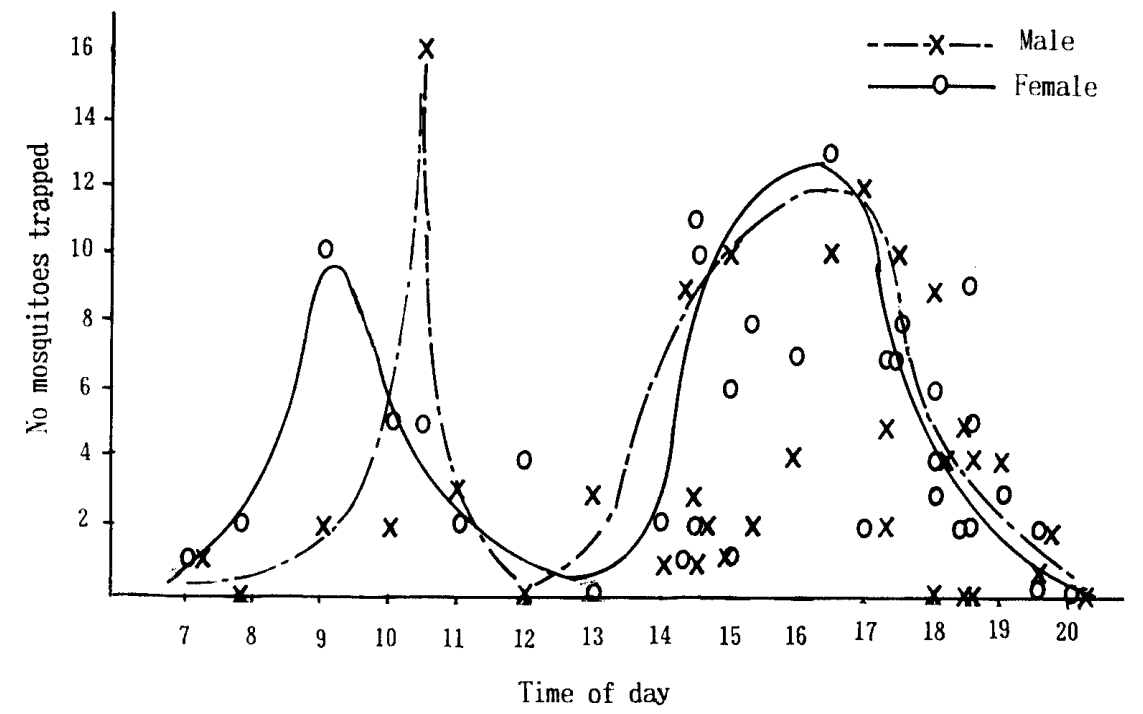

Fig. 3 Numbers of Aedes albopictus caught in the field by traps with various combinations of stimuli for $10 \mathrm{~min}$ at different times of days. of $\mathrm{CO}_{2}$, the heat, humidity and $\mathrm{CO}_{2}$-omitted combination (20) showed a reduced attractancy. In short, the heat-omitted combinations reduced attractancy most.

\section{Field experiment}

Daily activity of Ae. albopictus. The number of trapped mosquitoes in both sexes at different times of the day showed a bimodal pattern similar to Ae. aegypti, a small- er peak in the morning and a large one in the afternoon (Trips et al., 1973) (Fig. 3). Although different combinations of attractive stimuli were tested by the trap, the mosquito catches varied extensively even at the same time of day; the curves show their activity tendency as indicated by the maximum hourly catches. Therefore, only catches made at the hours of moderate and high activity, namely, from 9 to 11 and from 14 to 19 , 
Table 2 Numbers of mosquitoes caught by a back polyethylene trap with various combinations of stimuli.

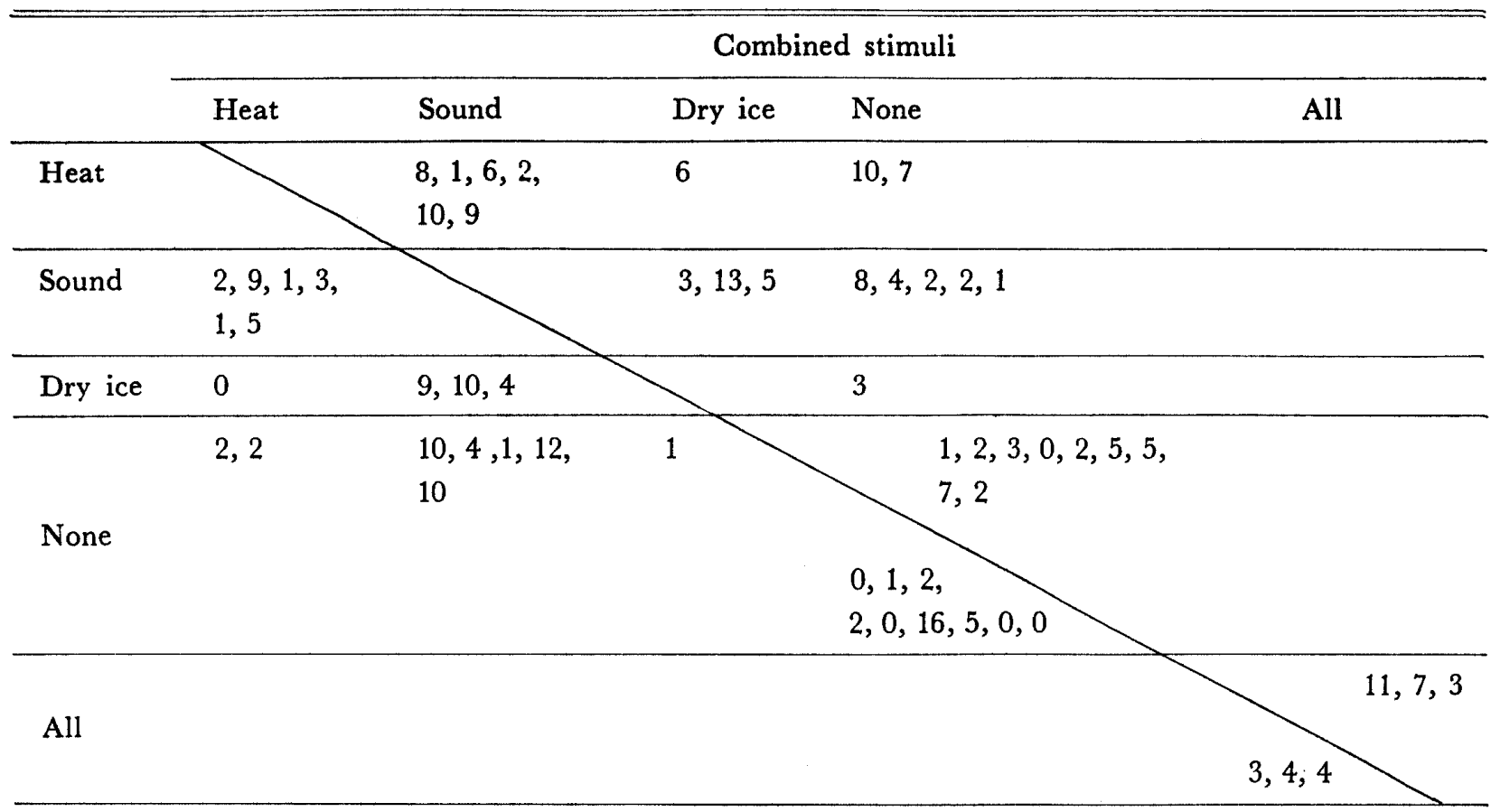

Figures above and below the diagonal show the numbers of female and male, respectively.

were considered in the following discussion.

Mosquito catch in a combination of various stimuli. The catch by the black polyethylene sheet trap varied extensively depending on the combinations of stimuli and among repetitions at different days and times of day (Table 2). The numbers above and below the diagonal in Table 2 show the catches of female and male, respectively. When the female catches with the heat combinations $(\bar{x}=6.7, n=12)$ (disregarding the other stimuli) were compared with those without heat $(\bar{x}=3.8, n=18)$, the difference was significant at $5 \%$ level by Man-Whitney's $U$-test (two-way test). On the other hand, the male catches with the heat combinations $(\bar{x}=3, n=12)$ were not significantly different from those without heat $(\bar{x}=4.8, n=18)$. Likewise, when the female catches with the sound combinations $(\bar{x}=5.6, n=17)$ were compared with those without sound $(\bar{x}=4.1$, $\mathrm{n}=13$ ), the difference was not significant at $5 \%$ level. On the contrary, the male catches with the sound combinations $(\bar{x}=5.4$, $n=17$ ) were significantly different from those without sound $(\bar{x}=1.3, n=12)$ at $1 \%$ level. The dry ice-combinations attracted neither more females $\bar{x}=6.4, n=8$ ) nor more males $(\bar{x}=4.4, n=8)$ than the combinations with- out dry ice, females $(\bar{x}=4.4, n=22)$ or males $(\bar{x}=4, n=22)$, respectively.

Comparison between the catches of different sexes by the same stimulus combinations was also of interest. With the heat combinations, significantly more female $(\bar{x}=6.7, n=12)$ was caught than male $(\bar{x}=3.0, n=12)$. In contrast, the female catches did not differ from the male catches with either sound, dry ice or no-stimulus combinations.

\section{Discussion}

Heat. Since Howlett first demonstrated in 1910 that warm air from a host was a signal for attack by mosquitoes, many researchers claimed convection current of heat as the most important stimulus for their attraction (Davis and Sokolove, 1975). In the present experiments, heat per se at 36$40^{\circ} \mathrm{C}$ or in combinations with other stimuli was reconfirmed to be the most important stimulus to Ae. aegypti in the laboratory and to Ae. albopictus in the field. In fact, the latter females were observed to be trapped mostly on and around the heat plate. However, heat works only at a short distance since the body surface temperature of human at $34^{\circ} \mathrm{C}$ 
reaches over only $40 \mathrm{~cm}$ to ambient temperature where the thermoreceptor of Ae. aegypti responds to a temperature change of $0.05^{\circ} \mathrm{C}$ (Davis and Sokolove, 1975). As aedine males follow females to a host for mating, some stimuli emanating from the host have been thought to attract the males as well. In fact, there was an indication of attractancy in heat in the present laboratory experiment, but no statistical difference between the mean male catches of the heat-treated and untreated traps was observed in the field experiment. In conclusion, heat is of prime importance in female attraction but not in male.

L-Lactic acid. Though host odor has long been investigated and many compounds isolated as the candidate attractants, only Llactic acid seems to show a moderate attractancy in laboratory experiments (Acree et al., 1968; Carlson et al., 1973). In the present laboratory experiment, this compound per se was certainly attractive at an optimum concentration and the combinations omitting this reduced attractancy to both sexes. Nevertheless, the attractancy could not be demonstrated in the field when $10 \mathrm{ml}$ of the neat compound was treated to the lower part of the trap sheet (the data is not shown). Since the actual evaporating rate of lactic acid is hard to define under field conditions, various amounts should be evaluated to conclude the attractancy.

Black color. Importance of visual factors, particularly a black silhouette, in orientation of day active and some night active mosquitoes is known (Gillies and Wikes, 1982; Bidlingmayer and Hem, 1979). One of the many black colored traps used in population sampling is a black cylinder suction trap, which attracted more females than males of Ae. aegypti and $C x$. quinquefasciatus (Wilton and Klotter, 1985). In the present laboratory experiment, black color, particularly B5 absorbing both UV and visual lights, was quite attractive to both sexes. The superior attractancy was also apparent with the black sheet B3 in the field experiment. The visually effective distance also varies depending on species from only $5 \mathrm{~m}$ of Culex decens to 9-18 $\mathrm{m}$ of Cx. tritaeniorhynchus and Anopheles spp. (Gillies and Wilkes, 1980 ), and $7.5 \mathrm{~m}$ of $C x$. quinquefasciatus to
15-20 m of many other species (Bidlingmayer and Hem, 1980). Although the attractive distance was not determined in the present field experiment, the black sheet of the size used is believed to have worked to a moderate distance as above referred.

Carbon dioxide. Regardless of the modus operandi of $\mathrm{CO}_{2}$, either attraction or mere excitation, many types of mosquito traps using $\mathrm{CO}_{2}$ per se or with other stimuli have been successfully employed for population sampling (Service, 1976). However, in the present experiment, $\mathrm{CO}_{2}$ showed attractancy by itself to neither sex. Even under the field condition, no significant attractancy was detected, although the gas delivery was not regulated.

Movement. The optokinetic sense of an insect is keen, and the mosquito utilizes this sense in host finding. A moving mouse in a transparent airtight container attracted 3.7 times more $A e$. aegypti than an anesthetized mouse in a similar one (Sippel and Brown, 1953). Field workers walking into aedineinfested area suspected that their movement was responsible for the initial attraction of host-seeking mosquitoes (Allan et al., 1987). Similar observation was made in the present field experiment; the majority of the trapped Ae. albopictus were brought near the trap by persons approaching through the bush. But other human stimuli dispersed into the air current might have also played an important role in the response to the trap. In the laboratory experiment, the movement of a black target with or without sound showed slightly more attractancy than a still one; this may be worth testing in the field in the future.

Sound. There are many publications on male attraction to the wingbeat sound of female, and acoustic sound has been used for control trials as mentioned in the INTRODUGTION. In fact, acoustic sound was the only significant attractant to male in the present field experiment. Interestingly, a few males, 5 males in one case, were often observed caught around a female which was desperately vibrating her wings with her legs stuck to the adhesive trap surface.

In conclusion, five physical and chemical stimuli per se showed some attractancy to both sexes of (except female not tested to 
movement) Ae. aegypti, but in combination tests, black color, heat and lactic acid proved superior attractants in this order. Under the field condition, however, only heat and sound when tested with a black sheet were significantly attractive to female and male of $A e$. albopictus, respectively. Analysis of attractants in human emanations and movement may further improve trap efficiency.

\section{REFERENCES}

Acree, F., Jr., R. B. Turner, H. K. Gouck, M. Beroza and N. Smith (1968): L-Lactic acid: A mosquito attractant isolated from humans. Science, 161: 1346-1347.

Allan, S. A., J. F. Day and J. D. Edman (1987) : Visual ecology of biting flies. Ann. Rev. Entomol., 32: 297-316.

Bidlingmayer, W. L. and D. G. Hem (1979): Mosquito (Diptera: Culicidae) flight behaviour near conspicuous objects. Bull. Entomol. Res., 69: $691-700$.

Bidlingmayer, W. L. and D. G. Hem (1980): The range of visual attraction and the effect of competitive visual attractants upon mosquito (Diptera: Culicidae) flight. Bull. Entomol. Res., 70: 321-342.

Carlson, D. A., N. Smith, H. K. Gouck and D. R. Godwin (1973): Yellow-fever mosquitoes: Compounds related to lactic acid that attract females. J. Econ. Entomol., 66: 329-331.

Clements, A. N. (1963) : The Physiology of Mosquitoes, 393 pp., Pergamon Press, Oxford.

Davis, E. E. and P. G. Sokolove (1975): Temperature responses of antennal receptors of the mosquito, Aedes aegypti. J. Comp. Physiol., 96: 223-236.

Gillies, M. T. and T. J. Wilkes (1980): The range of attraction of single baits for some West African mosquitoes. Bull. Entomol. Res., 60: $225-235$

Gillies, M. T. and T. J. Wilkes (1982): Responses of host-seeking Mansonia and Anopheles mosquitoes (Diptera: Culicidae) in West Africa to visual features of a target. J. Med. Entomol., 19: $68-71$.

Ikeshoji, T. (1986): Distribution of the mosquitoes. Culex tritaeniorhynchus, in relation to disposition of sound traps in a paddy field. Jpn. J. Sanit. Zool., 37: 153-159.

Ikeshoji, T., P. Langley and L. Gomulski (1990) : Genetic control by trapping. In: Appropriate Technology of Mosquito Control (ed., Curtis, G. F.), pp. 159-172, GRC Press, Florida.
Ikeshoji, T. and K. Ogawa (1988): Field catching of mosquitoes with various types of sound traps. Jpn. J. Sanit. Zool., 39: 119-123.

Ikeshoji, T., M. Sakakibara and W. K. Reisen (1985): Removal sampling of male mosquitoes from field populations by sound-trapping. Jpn. J. Sanit. Zool., 36: 197-203.

Ikeshoji, T. and H. H. Yap (1987): Monitoring and chemosterilization of a mosquito population, Culex quinquefasciatus (Diptera: Culicidae) by sound traps. Appl. Entomol. Zool., 22: 474481.

Kanda, T., W. H. Cheong, K. P. Loong, T. W. Lim, K. Ogawa, G. L. Chiang and S. Sucharit (1987): Collection of male mosquitoes from field populations by sound trapping. Trop. Biomed., 4: 161-171.

Leemingsawat, S. (1989) : Field trials of different traps for malaria vectors and epidemiological investigations at a foot-hill basin in Kanchanaburi, Thailand. Jpn. J. Sanit. Zool., 40: 171179.

Service, M. W. (1976): Mosquito Ecology. Field Sampling Methods, 583 pp., Appl. Sci. Publ., London.

Sippel, W. L. and A. W. A. Brown (1953): Studies on the responses of the female Aedes aegypti. Part V. The role of visual factors. Bull. Entomol. Res., 43: 567-574.

Trips, M., G. A. H. McCleelland, J. D. Gillett, C. Teesdale and T. R. Rao (1973): Diel periodicity in the landing of Aedes aegypti on man. Bull. W. H. O., 48: 623-629.

Wilton, D. P, and K. O. Klotter (1985): Preliminary evaluation of a black cylinder suction trap for Aedes aegypti and Culex quinquefasciatus (Diptera: Culicidae). J. Med. Entomol., 22: 113-114.

\section{摘 要 \\ Aedes 属に対する物理, 化学的刺激の 相対的な誘引性}

音響トラップによる雄蚊のみの捕獲より，雌雄蚊の 駆除のほうが有利である。そこでネッタイシマカ，七 トスジシマカに対して, 既知 7 種の物理，化学的刺激 の相対的な誘引性を比較した。 その結果, 熱, 乳酸, 黒色, 動き, 音は単独試験で, 雌雄のネッタイシマカ に対して誘引性を示した。しかし，混合刺激試験では， 黒色, 熱, 乳酸のみが,この順に強い誘引性を示した. マレーシアの森林境界でのヒトスジシマカ捕獾試験で は，熱と音のみがそれぞれ雌雄に対して有為な誘引性 を示した.より強力なトラップ製作のためには，動き (動視覚刺激) と強力な誘引臭の開発研究が望まれる. 